\title{
SIXTEEN YEARS OF PITYRIASIS VERSICOLOR IN METROPOLITAN AREA OF PORTO ALEGRE, SOUTHERN BRAZIL
}

Daiane HEIDRICH(1), Tatiane Caroline DABOIT(2), Cheila Denise Ottonelli STOPIGLIA(3), Cibele Massotti MAGAGNIN(1), Gerson VETORATTO(4), Taís Guarienti AMARO(4) \& Maria Lúcia SCROFERNEKER(1,5)

\begin{abstract}
SUMMARY
Pityriasis versicolor is the most common of the diseases caused by Malassezia yeasts. The aim of this study is to determine the prevalence of pityriasis versicolor and its etiological aspects in the metropolitan area of Porto Alegre, Brazil. A retrospective crosssectional study with data from patients of a reference hospital from 1996 to 2011 was performed. Collected data included: date, age, gender, ethnicity, anatomical region of lesion and the direct mycological examination results. Among the positive results in the direct mycological examination, $5.8 \%(2,239)$ were positive for pityriasis versicolor. The angular coefficient (B) was $-0.3 \% / y e a r$, showing a decrease over the years. The disease was more prevalent in men $(7.1 \%$ of men versus $5.1 \%$ of women that underwent the direct mycological examination); younger age (median 31 years old); "pardo" and black people (3.7\% more than expected in the sample); trunk (73.44\% of the affected anatomic sites). Lesions in rare sites (groin, genitals, legs, feet and hands) were also observed in this study. In conclusion, due to the decrease in the prevalence of pityriasis versicolor, long-term epidemiological studies in the metropolitan area of Porto Alegre, Brazil, are needed to continue the monitoring of this disease.
\end{abstract}

KEYWORDS: Epidemiology; Dermatology; Malassezia spp.; Tinea versicolor.

\section{INTRODUCTION}

Pityriasis versicolor or tinea versicolor is the most common of the diseases caused by Malassezia yeasts and is characterized by the development of hypo or hyperpigmented scaly spots, being more frequent in the upper trunk ${ }^{33}$. Pityriasis versicolor is asymptomatic or oligosymptomatic, with mild or moderate pruritus ${ }^{8,17}$, but recurrences of the disease are frequent. Although this disease does not threaten function or life and, in most cases, presents good response to treatment, the clinical aspect of the lesions and the residual hypochromia or achromia that the disease may cause leads to great social stigma ${ }^{23}$.

The genus Malassezia comprises lipophilic yeasts belonging to the normal cutaneous microbiota of humans and warm-blooded animals ${ }^{15,16}$. However, this yeast can also cause lesions with distinct absence of inflammation despite the heavy fungal load (pityriasis versicolor), or it can be involved with diseases that lead to characteristic inflammation (eg, seborrheic dermatitis, atopic dermatitis, folliculitis), or even systemic infections ${ }^{12,25}$. An important differentiating characteristic is that other conditions similar to Malassezia appear only in the yeast form, whereas the fungus in tinea versicolor appears in the dimorphic form. It is seen as spaghetti and meatballs under potassium hydroxide preparation, where spaghetti represents the pseudo-hyphae and meatballs the round spores ${ }^{18}$.
Currently, 14 species of Malassezia are known, seven described in 1996 (M. globosa, M. restricta, M. furfur, M. sympodialis, M. slooffiae, $M$. obtuse and $M$. pachydermatis), which are the most prevalent, according to a review by GAITANIS et al. $(2012)^{11}$. The other seven are new species discovered during the last decade (M. dermatis, M. japonica, M. nana, $M$. yamatoensis, M. equina, M. caprae and $M$. cuniculi); molecular analysis is required to distinguish among these species ${ }^{11,12}$. Until now, no specific species for tinea versicolor, or for the remaining Malassezia-associated diseases were found. However, there seem to be geographical variations in the distribution of Malassezia species in the world, but more studies are required for confirmation ${ }^{12}$.

There are several contributing factors that can increase the likelihood of pathological overgrowth of Malassezia spp. These include the application of oily preparations and creams (due to the lipophilicity of the organisms), an increase in environmental humidity, corticosteroid overuse, and genetic predisposition ${ }^{18}$.

Pityriasis versicolor is one of the dermatologic diseases most frequently observed in clinical practice in the extreme south of Brazil, and therefore, the aim of this study was to determine the prevalence of pitiryasis versicolor and its etiological aspects. 
HEIDRICH, D.; DABOIT, T.C.; STOPIGLIA, C.D.O.; MAGAGNIN, C.M.; VETORATTO, G.; AMARO, T.G. \& SCROFERNEKER, M.L. - Sixteen years of pityriasis versicolor in metropolitan area of Porto Alegre, Southern Brazil. Rev. Inst. Med. Trop. Sao Paulo, 57(4): 277-80, 2015.

Table 1

Statistical tests performed and programs used for each objective

\begin{tabular}{ll}
\hline Objectives & Tests $(\alpha=0.05)$ \\
$\begin{array}{l}\text { Determine the behavior of the prevalence over the years. } \\
\text { Compare the prevalence of disease between the genders. }\end{array}$ & $\begin{array}{l}\text { Simple linear regression } \\
\text { Pearson's Chi-square } \\
\text { Compare the patients ages between the genders. }\end{array}$ \\
$\begin{array}{l}\text { Compare ethnic proportion of cases of pityriasis versicolor with the sample proportion and } \\
\text { determine which ethnic groups are responsible for the statistical difference. }\end{array}$ & $\begin{array}{l}\text { Chi-square/Chi-square corrected } \\
\text { by Bonferroni }\end{array} \quad \begin{array}{l}\text { SPSS } \\
\text { WinPEPI }\end{array}$ \\
\hline
\end{tabular}

* SPSS version 18, R version 13.2 and WinPEPI version 11.25 .

\section{MATERIAL AND METHODS}

A retrospective cross-sectional study was performed using data, including direct mycological examination, collected from patients attended at the Department of Dermatology of Complexo Hospitalar Santa Casa de Porto Alegre, south of Brazil, from January 1996 to December 2011. The research was approved by the Hospital Ethics Committee under the protocol number 3484/11.

Skin was collected by means of scraping injured surfaces with microscope slides. The material was clarified with $20 \%$ potassium hydroxide and examined under an optical microscope. A test was considered positive for pityriasis versicolor whenever hyphae and yeast cells of Malassezia sp. with "spaghetti and meatballs" appearance were found ${ }^{12,18}$.

Recorded data included: date, age, gender, ethnicity, anatomical region of the lesion and the direct mycological examination results. Ethnicity classification (white, "pardo", and black) was considered, according to the Brazilian Institute of Geography and Statistics, (IBGE). The distribution of ethnic groups was called sample proportion, including all subjects who underwent the direct mycological examination during the study period.

The anatomical areas of the lesions were: face, trunk, arms, legs, groin and genitals, feet and hands. Statistical tests were performed, and the program to calculate each of the parameters evaluated in the study is described in Table 1. For each analysis, cases with missing value in the variable to be analyzed were excluded. In order to carry out the simple linear regressions of the genus Malassezia, the annual prevalence among all positive results was considered, regardless the detected fungus, where $\mathrm{x}=$ year and $\mathrm{y}=$ (no. of genus in the year/total number of positive tests in the year) $\mathrm{x} 100$.

\section{RESULTS}

Of the 71,463 examined cases, 38,520 (53.9\%) were positive for fungi and $5.8 \%(2,239)$ of these were positive for Malassezia sp. presenting with typical structures of pityriasis versicolor. The angular coefficient (B) was $-0.3 \%$ / year, showing a decrease over the years when compared with the direct mycological examination results $(p<0.001)$.

Table 2 shows that pityriasis versicolor was more frequent in men than in women $(7.1 \%$ and $5.1 \%$ of all positive results of the direct mycological examination, respectively). But there was no difference between the ages of men and women (31 years old for both genders). However, the higher prevalence was in the age group of 21 to 30 years old, with $28.2 \%$ and $26.8 \%$ of the men and women affected, respectively (Fig. 1).
Pityriasis versicolor affected more "pardo" and black and less white patients than the expected, with $3.7 \%$ more "pardo" and black patients than expected when compared with the ethnic proportion of patients who underwent the direct mycological examination during the study period (Fig. 2). Trunk was the region of the body more affected, with $74.71 \%$ of the cases (Fig. 3).

Table 2

Age and prevalence of pityriasis versicolor between genders in the metropolitan area of Porto Alegre, Brazil (1996-2011)

\begin{tabular}{cccc}
\hline & \multicolumn{2}{c}{ Gender } & \multirow{2}{*}{$p$} \\
\cline { 2 - 3 } & Male & Female & \\
\hline Median Age (quartis 25/75) & $31(21 / 46)$ & $31(21 / 44)$ & 0.218 \\
number of cases & 885 & 1240 & \\
Infection (\%) & 7.1 & 5.1 & $<0.01$ \\
number of cases & 941 & 1298 & \\
number of positive direct & 13223 & 25411 & \\
examination for any fungi & & & \\
\hline
\end{tabular}

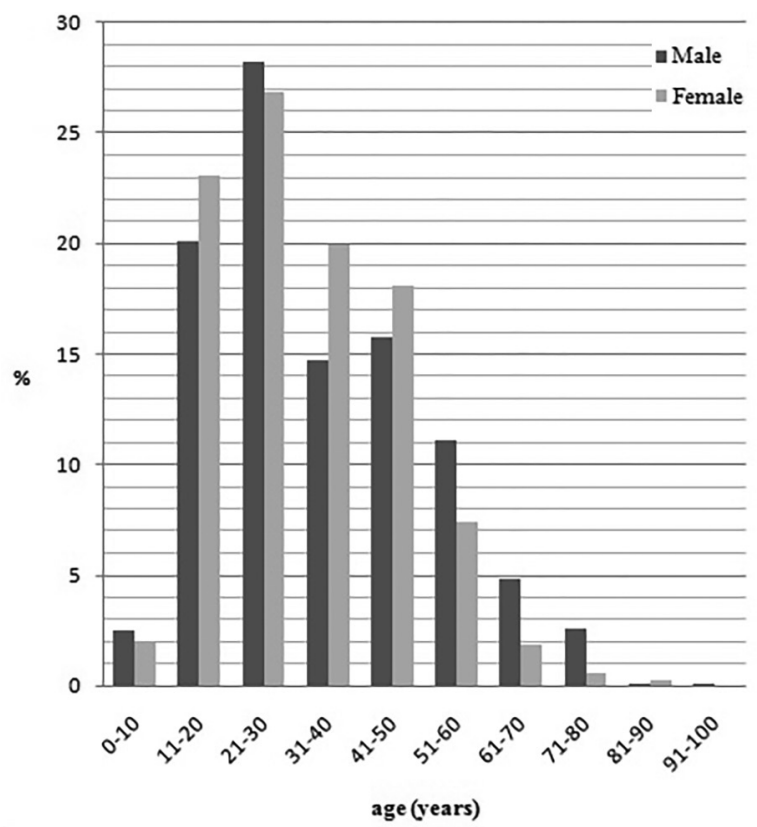

Fig. 1 - Prevalence of age of male and female patients with pityriasis versicolor in the metropolitan area of Porto Alegre, Brazil (1996-2011). 


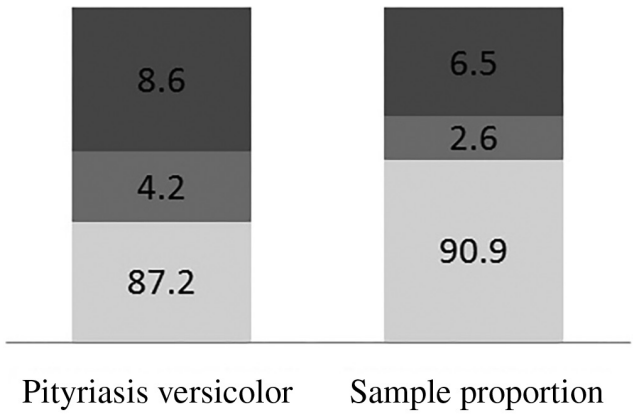

\section{"White " "Pardo" "Black}

Fig. 2 - Ethnic proportion in pityriasis versicolor in comparison with the sample proportion $(\%)$ in the metropolitan area of Porto Alegre, Brazil (1996-2011). $p<0.001$; Number of cases $=2150 ;$ Ethnic sample proportion $=$ all patients submitted to mycological direct examination $(\mathrm{n}=68,385)$.

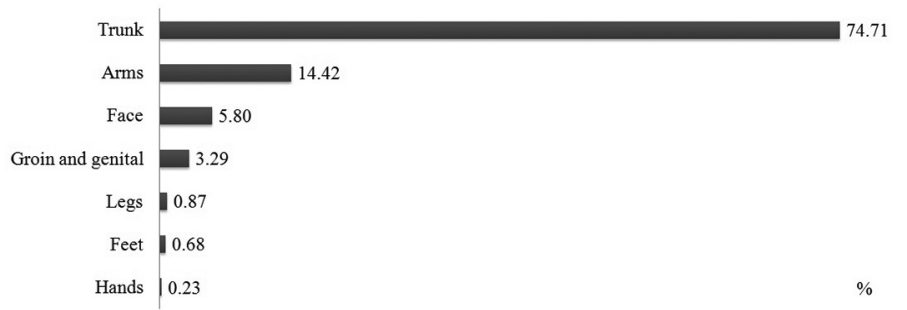

Fig. 3 - Prevalence of pityriasis versicolor in anatomical sites of lesions (\%) in the metropolitan area of Porto Alegre, Brazil (1996-2011). Number of cases = 2,229.

\section{DISCUSSION}

Pityriasis versicolor is a chronic superficial fungal infection caused by the yeasts of Malassezia genus and it can affect $40 \%$ to $50 \%$ of individuals in certain geographic regions and ethnic groups. In tropical regions, it is a common dermatosis because of the high humidity and temperature increasing its prevalence ${ }^{23}$. Some authors found Malassezia spp. in about $26 \%$ of cases of dermatomycoses in this type of climate ${ }^{7,9,30}$. However, KOKSAL et al. $(2009)^{20}$ found yeast in $3 \%$ of cases of dermatomycoses in Istanbul, close to the value obtained in our study (5.8\%). This similarity can be explained by the type of climate, since both regions are temperate, and in this climate pityriasis versicolor tends to recur annually in summer ${ }^{21}$.

In the literature, there are no studies on the monitoring of this disease over the years. We found a decrease of $0.3 \%$ per year in pityriasis versicolor prevalence. This decrease may be related to a lower human exposure to the sun, which would lead to a reduced demand for medical assistance, knowing that injuries are often perceived by the patient only after sun exposure, when alteration of skin pigmentation caused by the fungus is contrasted with tanned skin, especially when the lesion is hypochromic ${ }^{17}$. Another possibility would be a real decrease in disease frequency in comparison with dermatomycoses caused by other fungi such as dermatophytes and Candida spp. The percentage of pityriasis versicolor was found to be higher in males than in females when compared with other positive results of the direct mycological examination. Many studies show higher disease prevalence in male subjects ${ }^{10,13,19,20,23,27}$, being the higher prevalence in this gender due to increased sebaceous activity in men $^{18}$, but some authors found no difference in prevalence between genders ${ }^{1,14,25}$. Despite the higher number of female patients with pityriasis versicolor in our study, we could not determine this gender as the most affected, because this data is related to the high number of female patients who underwent the direct mycological examination. Thus, some authors reported a higher prevalence of the disease in women ${ }^{22,24,29}$, but this can be attributed to the fact that women seek medical care more frequently than men due to the extra attention women pay to beauty and skin hygiene ${ }^{29,31}$.

We observed a higher prevalence of the disease at a younger age (median 31 years old), which is in agreement with many studies $1,10,13,19,23,24,26,27,29,31$. This fact can be explained by the increased activity of sebaceous glands during puberty in young adults, which is an important endogenous factor. Thus, the increase in secretion of sebum on the skin favors the growth of Malassezia yeasts ${ }^{1,4,23,27}$.

Higher prevalence of the disease in black and "pardo" patients was found when compared with the proportion of white, "pardo" and black ethnic groups of patients submitted to the direct mycological examination. CHILD et al. (1999) ${ }^{6}$ also found a statistically significant predilection of tinea versicolor for darker skin types in southeastern London (48\% in black people and $35 \%$ in white). However, these results may be associated with the greatest apparent visualization of lesions in darkskinned individuals ${ }^{5}$, causing a social stigmatization when extensive depigmentation happens in colored skin people ${ }^{11}$. Thus, we believe that patients of "pardo" and black ethnicities seek medical care more often than white patients when suffering from this disease.

Trunk was the region of the body most affected, with $74.71 \%$ of the cases, which is in agreement with the many studies worldwide ${ }^{1,13,14,22,23,24,27,29,31}$. Many authors related the fact to the density and to the activity of pilosebaceous glands in this area ${ }^{1,27,31}$. Over the 16 years of study, we found lesions caused by Malassezia spp. related to pityriasis versicolor in several locations of the body, including legs, feet and hands that had not been reported in other epidemiological studies to date, since most of the studies had a lower number of patients and thus they could not display anatomical sites that are more rarely affected by the disease. However, in the literature, there are reports of cases showing lesions in unusual anatomic sites, which were also observed along our study, as groin, genitals, legs, feet and hands $\mathrm{s}^{2,3,28,32}$.

In conclusion, our study corroborates the data in the literature regarding the higher prevalence of pityriasis versicolor in men, younger ages, and in "pardo" and black people. As in other studies, the trunk was the body site most affected by the disease, but in this study, lesions in more unusual sites were found, fact that had not been observed in other epidemiological studies to date. Furthermore, there was a decrease in pityriasis versicolor over the sixteen years of study. Therefore, long-term epidemiological studies in the metropolitan area of Porto Alegre, Brazil, are needed to continue the monitoring of this disease.

\section{RESUMO}

\section{Dezesseis anos de pitiríase versicolor na Região Metropolitana de Porto Alegre, Sul do Brasil}

Pitiríase versicolor é a mais comum das doenças causadas pelas leveduras do gênero Malassezia. O objetivo do trabalho foi determinar a prevalência de pitiríase versicolor e seus aspectos etiológicos na 
HEIDRICH, D.; DABOIT, T.C.; STOPIGLIA, C.D.O.; MAGAGNIN, C.M.; VETORATTO, G.; AMARO, T.G. \& SCROFERNEKER, M.L. - Sixteen years of pityriasis versicolor in metropolitan area of Porto Alegre, Southern Brazil. Rev. Inst. Med. Trop. Sao Paulo, 57(4): 277-80, 2015.

região metropolitana de Porto Alegre, Brasil. Foi realizado um estudo retrospectivo transversal com dados de pacientes de hospital de referência entre 1996 a 2011. Os dados coletados foram: data, idade, gênero, etnia, local anatômico da lesão e resultados do exame micológico direto. Dentre os resultados positivos do exame micológico direto, 5,8\% (2.239) foram positivos para pitiríase versicolor. O coeficiente angular (B) foi $-0,3 \%$ l ano, mostrando uma diminuição ao longo dos anos. A doença foi mais prevalente em homens $(7,1 \%$ dos homens versus $5,1 \%$ das mulheres que se submeteram ao exame micológico direto); jovens (mediana de 31 anos); pardos e pretos (3,7\% acima do esperado para a amostra); tronco (73,4\% dos locais anatômicos afetados). Lesões em locais raros (virilha, genitálias, pernas, pés e mãos) também foram observadas no estudo. Em conclusão, devido à diminuição da prevalência de pitiríase versicolor, estudos epidemiológicos de longo prazo são necessários para continuar o monitoramento da doença na região metropolitana de Porto Alegre, Brasil.

\section{ACKNOWLEDGMENTS}

The authors want to thank Prof. Cleusa Brilhante for her assistance in compiling the data, the Coordenação de Aperfeiçoamento de Pessoal de Nivel Superior (CAPES) and the Conselho Nacional de Desenvolvimento Científico e Tecnológico $(\mathrm{CNP} q)$ for providing the scholarships.

\section{REFERENCES}

1. Afshar P, Ghasemi M, Kalhori S. Identification of Malassezia species isolated from patients with pityriasis versicolor in Sari, Iran, 2012. Jundishapur J Microbiol. 2013;6:e8581.

2. Akaberi AA, Amini SS, Hajihosseini H. An unusual form of tinea versicolor: a case report. Iranian J Dermatol. 2009;12(Suppl):S30-1.

3. Aste N, Pau M, Aste N. Pityriasis versicolor on the groin mimicking erythrasma. Mycoses. 2004;47:249-51.

4. Bélec L, Testa J, Bouree P. Pityriasis versicolor in the Central African Republic: a randomized study of 144 cases. J Med Vet Mycol. 1991;29:323-9.

5. Berry M, Khachemoune A. Extensive tinea versicolor mimicking Pityriasis rubra pilaris. J Drugs Dermatol. 2009;8:490-1.

6. Child FJ, Fuller LC, Higgins EM, Du Vivier AWP. A study of the spectrum of skin disease occurring in a black population in south-east London. Br J Dermatol. 1999;141:512-7.

7. Ellabib MS, Khalifa ZM. Dermatophytes and other fungi associated with skin mycoses in Tripoli, Libya. Ann Saudi Med. 2001;21:193-5.

8. Faergemann J. Pityriasis versicolor. Semin Dermatol. 1993;12:276-9.

9. Ferié J, Dinkela A, Mbata M, Idindili B, Schmid-Grendelmeier P, Hatz C. Skin disorders among school children in rural Tanzania and an assessment of therapeutic needs. Trop Doct. 2006;36:219-21.

10. Framil VM, Melhem MS, Szeszs MW, Zaitz C. New aspects in the clinical course of pityriasis versicolor. An Bras Dermatol. 2011;86:1135-40.

11. Gaitanis G, Magiatis P, Hantschke M, Bassukas ID, Velegraki A. The Malassezia genus in skin and systemic diseases. Clin Microbiol Rev. 2012;25:106-41.

12. Gaitanis G, Velegraki A, Mayser P, Bassukas ID. Skin diseases associated with Malassezia yeasts: facts and controversies. Clin Dermatol. 2013;31:455-63.

13. Ghosh SK, Dey SK, Saha I, Barbhuiya JN, Ghosh A, Roy AK. Pityriasis versicolor: a clinicomycological and epidemiological study from a tertiary care hospital. Indian J Dermatol. 2008;53:182-5.
14. Giusiano G, Sosa MA, Rojas F, Vanacore ST, Mangiaterra M. Prevalence of Malassezia species in pityriasis versicolor lesions in northeast Argentina. Rev Iberoam Micol. 2010;27:71-4

15. Guého E, Boekhout T, Ashbe HR, Guillot J, van Belkum A, Faergemann J. The role of Malassezia species in the ecology of human skin and as pathogens. Med Mycol. 1998;36(Suppl 1):220-9.

16. Guillot J, Bond R. Malassezia pachydermatis: a review. Med Mycol. 1999;37:295-306.

17. Gupta AK, Bluhm R, Summerbell RC. Pityriasis versicolor. J Eur Acad Dermatol Venereol. $2002 ; 16: 19-33$.

18. Kallini JR, Riaz F, Khachemoune A. Tinea versicolor in dark-skinned individuals. Int J Dermatol. 2014;53:137-41.

19. Karakas M, Turaç-Bíçer A, Ílkít M, Durdu M, Seydaoglu G. Epidemiology of pityriasis versicolor in Adana, Turkey. J Dermatol. 2009;36:377-82.

20. Koksal F, Er E, Samasti M. Causative agents of superficial mycoses in Istanbul, Turkey: retrospective study. Mycopathologia. 2009;168:117-23.

21. Levin NA. Beyond spaghetti and meatballs: skin diseases associated with the Malassezia yeasts. Dermatol Nurs. 2009;21:7-13.

22. Miranda KC, de Araujo CR, Soares AJ, Lemos JA, Souza LKH, Silva MRR. Identificação de espécies de Malassezia em pacientes com pitiríase versicolor em Goiânia-GO. Rev Soc Bras Med Trop. 2006;39:582-3.

23. Morais PM, Cunha MGS, Frota MZM. Clinical aspects of patients with pityriasis versicolor seen at a referral center for tropical dermatology in Manaus, Amazonas, Brazil. An Bras Dermatol. 2010;85:797-803.

24. Petry V, Tanhausen F, Weiss L, Milan T, Mezzari A, Weber MB. Identification of Malassezia yeast species isolated from patients with pityriasis versicolor. An Bras Dermatol. 2011;86:803-6.

25. Ramadán S, Sortino M, Bulacio L, Marozzi ML, López C, Ramos L. Prevalence of Malassezia species in patients with pityriasis versicolor in Rosario, Argentina. Rev Iberoam Micol. 2012;29:14-9.

26. Rao GS, Kuruvilla M, Kumar P, Vinod V. Clinico-epidermiological studies on tinea versicolor. Indian J Dermatol Venereol Leprol. 2002;68:208-9.

27. Rasi A, Naderi R, Behzadi AH, Falahati M, Farehyar S, Honarbakhsh Y, et al. Malassezia yeast species isolated from Iranian patients with pityriasis versicolor in a prospective study. Mycoses. 2009;53:350-5.

28. Romano C, Feci L, Mancianti F, Fimiani M. Perineal and genital pityriasis versicolor due to Malassezia globosa. J Eur Acad Dermatol Venereol. 2014. doi: 10.1111/jdv.12547.

29. Santana JO, de Azevedo FLA, Campos Filho PC. Pityriasis versicolor: clinicalepidemiological characterization of patients in the urban area of Buerarema-BA, Brazil. An Bras Dermatol. 2013;88:216-21.

30. Tan HH. Superficial fungal infections seen at the National Skin Centre, Singapore. Nihon Ishinkin Gakkai Zasshi. 2005;46:77-80.

31. Tarazooie B, Kordbacheh P, Zaini F, Zomorodian K, Saadat F, Zeraati H, et al. Study of the distribution of Malassezia species in patients with pityriasis versicolor and healthy individuals in Tehran, Iran. BMC Dermatol. 2004;4:5.

32. Varada S, Dabade T, Loo DS. Uncommon presentations of tinea versicolor. Dermatol Pract Concept. 2014;4:93-6.

33. Veer P, Patwardhan NS, Damle AS. Study of onychomycosis: prevailing fungi and pattern of infection. Indian J Med Microbiol. 2007;25:53-6.

Received: 11 September 2014

Accepted: 14 November 2014 